\title{
UPAH PEMBUATAN KANDANG PUYUH DALAM TINJAUAN FIQH MUAMALAH (Studi di Jorong Kamboja Nagari Lubuak Jantan)
}

\author{
Ramadhona Halim Putra1, Nurhikma ${ }^{2}$ \\ ${ }^{1}$ Institut Agama Islam Negeri (IAIN) Batusangkar \\ e-mail: ramadhonahalim14@gmail.com \\ 2 Institut Agama Islam Negeri (IAIN) Batusangkar \\ e-mail: nurhikma@iainbatusangkar.ac.id
}

\begin{abstract}
The main problem in this study is how to pay wages for making cages in Jorong Cambodia, Nagari Lubuk Jantan, North Lintau Buo District, Tanah Datar Regency, and how to review muamalah fiqh on wages for making quail cages in Jorong Cambodia, Nagari Lubuk Jantan, North Lintau Buo District, Tanah Regency. Flat. The purpose of this study was to find out and explain the wages for making quail cages and explain the fiqh muamalah review of wages for making quail cages in Jorong Cambodia, Nagari Lubuk Jantan, North Lintau Buo District. The type of research that the author uses is qualitative research, while the nature of the research is descriptive qualitative. Qualitative descriptive research is to describe phenomen a that occur in the field as they are according to reality. Data collection was carried out using interview and documentation techniques. Based on the results of the research that the author did, it was concluded that the implementation of the wage system in the manufacture of quail cages, the owner of the cage asked for the contents of one box of 40 quails, then the total wages of one box was Rp. 120,000,-. If one row of wages Rp. 9,000,000, - then after the cage is ready, the owner fills a box with 50 quails, then the craftsman suffers a loss in one box of $\mathrm{R}$. 30.000,-. one row of 75 boxes, the craftsman suffers a loss of $\mathrm{R} p$. 2.250.000,- in one row of quail cages. The form of aqad carried out by the owner of the cage with the worker who made the cage verbally, this is not in accordance with the agreement because there is an element of gharar which is not allowed because it will cause harm to one party or a mutual agreement and harm the party concerned. Overview of Fiqh Muamalah on wages in making The quail cage that occurred in Jorong Cambodia Nagari Lubuk. Jantan was not in accordance with the Fiqh Muamalah concept because there was a loss caused by one of the parties. Islam forbids anything that harms one of the parties to the muamalah, every loss and harm must be eliminated.
\end{abstract}

Keywords: Wages for Making Quail Cages, Muamalah

\section{PENDAHULUAN}

Allah menciptakan manusia untuk hidup rukun saling berdampingan dan saling membutuhkan antara satu individu dengan individu lainnya. Setiap orang tidak selalu memiliki apa yang di butuhkannya, tetapi orang lain memiliki sebagian dari apa yang tidak dibutuhkannya. Oleh karena itu diperlukan bantuan orang lain untuk melengkapi kebutuhan dari seseorang tersebut. Seseorang tidak bisa hidup sendiri tanpa bantuan orang lain, dengan kata lain manusia adalah makhluk sosial. (Ahmad, 2000: 11)

Dalam melakukan pemenuhan kebutuhan secara timbal balik, manusia sebagai makhluk sosial diatur oleh Allah SWT sebagaimana dalam Islam dikenal dengan istilah muamalat diantaranya sewa-menyewa, upah, jual beli, gadai, kerja sama dan lain sebagainya. Diantara berbagai macam muamalat yang dilakukan oleh manusia selain dari jual beli ada juga yang paling sering dijumpai dalam kehidupan sehari-hari diantaranya yaitu upah mengupah atau disebut dengan ujrah. 


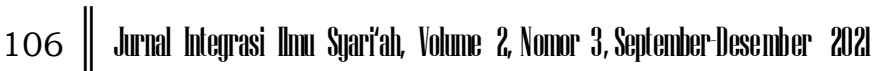

Upah adalah memberikan imbalan sebagai bayaran kepada seseorang yang telah diperintah untuk mengerjakan suatu pekerjaan tertentu dan bayaran yang diberikan menurut perjanjian yang telah disepakati.

Upah biasanya ditetapkan oleh kedua belah pihak dalam perjanjian kerja, dalam peraturan majikan, dalam peraturan upah atau dalam perjanjian pemburuhan. Ada kemungkinan bahwa dalam perjanjian dan peraturan tidak dapat ketentuan mengenai upah, pada umumnya ditarik kesimpulan bahwa kedua belah pihak telah bersepakat bahwa penetapan akan dilakukan oleh majikan secara sepihak. Dengan sendirinya majikan harus menetapkannya dengan iktikad baik.

Upah dalam literatur figh sering dibahasakan dengan ajran, ketentuannya telah ditetapkan sedemikian rupa sehingga dapat memenuhi keadilan dan tidak merugikan salah satu pihak baik majikan maupun buruh itu sendiri. Pengupahan bagi buruh harus sesuai dengan ketentuan norma yang telah ditetapkan. Tetapi pada praktisnya yang terjadi dilapangan sering terjadi ketimbangan dan banyak penyimpangan, dan muncul berbagai permasalahan yang menimbulkan rasa ketidakadilan bagi para buruh dalam penetapan upah selama ini. (Nufus, 2020: 2-4).

Masyarakat Jorong Kamboja Nagari Lubuk Jantan Kecamatan Lintau Buo Utara melakukan praktek upah mengupah. Salah satu diantaranya adalah praktek upah mengupah dalam hal membuat kandang puyuh. Berdasarkan observasi awal yaitu melakukan wawancara anatara penulis dengan Wahyudi di Jorong Kamboja pada hari Jumat, 04 Desember 2020. Selaku tukang yang membuat kandang puyuh, ia menjelaskan tentang pembuatan kandang puyuh di Jorong Kamboja. Perjanjian pembuatan kandang puyuh tersebut tukang di suruh untuk membuatkan kandang puyuh dengan isi 1 kotak nya 40 ekor dengan upah per ekor 1 ekor nya Rp 3.000,--

Bentuk kandang puyuh pada satu kandang bisa 2 baris ke kiri dan kanan. Bentuk pembuatan kandang puyuh tersebut persegi panjang dengan ukuran 5x12 m, kemudian dibagi menjadi kotak-kotak kecil dengan ukuran1x80 m. Total kotak dalam satu deret adalah 75 yang terdiri dari 5 kotak ke atas dan 15 kotak ke samping. Sistem upah dalam pembuatan kandang puyuh dihitung dari per ekor puyuh dalam kotak, dengan harga satu ekor Rp 3.000,-. Apabila pemilik kandang meminta satu kotak di isi dengan 40 ekor puyuh, maka jumlah upah per kotak 40 ekor $\times 3.000,-=R p 120.000,-$. Sehingga satu barisnya dikenakan upah 120.000,- x 75 kotak $=\operatorname{Rp} 9.000 .000,-$ dengan jumlah 1 baris kandang puyuh ber isi 3.000 ekor puyuh dan ternyata setelah kandang siap pemilik mengisi satu kotak dengan 50 ekor puyuh. Jika di isi satu kotaknya 50 ekor puyuh oleh pemilik kandang, maka tukang mengalami kerugian dalam satu kotaknya Rp 3.000.- x 10 ekor puyuh $=\operatorname{Rp} 30.000$,- Satu baris nya 75 kotak kalau di isi 50 ekor 1 kotak nya dalam 1 baris nya puyuh berjumlah 75 kotak $x 50$ ekor $=3.750$ ekor puyuh maka tukang mengalami kerugian 1 kotak nya sebanyak Rp 30.000,- x 75 kotak $=\operatorname{Rp} 2.250 .000,-$ dalam 1 barisnya dengan upah 1 ekor Rp 3.000,-. Jumlah kotak sebanyak 75 kotak terdiri dari Wawancara juga dilakukan dengan Irsal selaku pemilik kandang puyuh di Jorong Kamboja pada hari Jumat, 04 Desember 2020 ia menjelaskan bahwa satu kotak kandang puyuh tersebut di isi dengan 50 ekor puyuh, 5 kotak ke atas dan 15 ke samping. Untuk total upah yang diterima tukang adalah Rp 11.250.000,-. Syarat dan rukun ijarah adanya 
aqid (orang yang berakad), adanya sighat akad (ucapan), adanya upah, dan adanya manfaat. Namun, dalam perjanjiannya tidak sesuai (menyimpang).

\section{METODE PENELITIAN}

Jenis penelitian yang dipakai adalah penelitian kualitatif (field research). Lokasi penelitian bertempat di Jorong Kamboja Nagari Lubuk Jantan Kecamatan Lintau Buo Utara, subjek dari penelitian ini adalah pemilik kandang dan tukang pembuat kandang puyuh, karena tujuan daari penelitian ini adalah untuk mengetahui bagaimana sistem pelaksanaan upah mengupah membuat kandang puyuh di tinjau dari fiqh muamalah. Latar penelitian yang penulis lakukakan bertempat di Jorong Kamboja Nagari Lubuk Jantan Kecamatan Lintau Buo Utara. Sumber data yang digunakan adalah sebagai berikut: Data primer diperoleh langsung dari sumbernya yaitu dengan melalui wawancara langsung kepada tukang pembuat kandang puyuh dan peternak puyuh yang berjumlah 9 orang yaitu Wahyudi, Ismail, Betrianto, Pendi, sebagai tukang pembuat kandang puyuh, Irsal, Bustanil, Afrizal, Jalinus, Reni Susanti Sebagai pemilik kandang. Sumber data sekunder adalah data yang di peroleh dari bahan yang bukan sumber pertama atau informasi yang digunakan untuk menjawab masalah ini bersumber dari buku, dokumen, jurnal, penelitian yang berhubungan dengan pemersalahan yang penulis teliti.

\section{HASIL DAN PEMBAHASAN}

Perspektif merupakan pandangan akan suatu hal atau suatu objek yang diterima melalui panca indera (Walgito, 2008: 87) Perspektif disini ialah pandangan masyarakat akan suatu hal yaitu harta bersama bagi istri yang bekerja membantu suami dalam pemenuhan kebutuhan keluarga atau sebagai pencari nafkah utama dalam suatu keluarga. Pandangan tersebut dikategorkan dalam 3 hal yaitu pengetahuan, pemahaman serta pelaksanaan yang terjadi ditengah masyarakat akan hal itu.

Kondisi geografis nagari lubuk jantan

a. Luas Wilayah

Nagari Lubuk Jantan merupakan salah satu dari 5 Nagari yang ada di

Kecamatan Lintau Buo Utara dengan luas wilayah 7.894 Ha yang terdiri dari 11 (sebelas) Jorong.

b. Batas-batas Nagari Lubuk Jantan

Secara Administratif Nagari Lubuk Jantan berbatasan dengan :

Sebelah Utara : Nagari Tepi Selo, Nagari Balai Tengah dan Tanjung Bonai

Sebelah Selatan : Nagari Buo

Sebelah Barat : Nagari Tepi Selo

Sebelah Timur : Kecamatan Sumpur Kudus Kab Sijunjung

Suatu akad dipandang sah jika telah memenuhi rukun dan syarat. Rukun dan syarat saling berkaitan. begitu juga dengan pembuat kandang puyuh dan peternak puyuh yang berada di Jorong Kamboja Nagari Lubuk Jantan Kecamatan Lintau Buo Utara menggunakan akad secara lisan Sebelum pembuatan kandang puyuh, tidak ada bentuk 


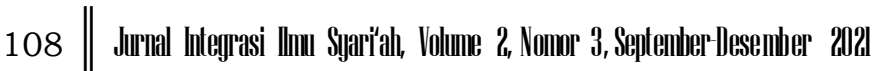

akad tertulis yang mengatur pekerja antara pemilik kandang. Pelaksanaan upahMengupah pembuatan kandang puyuh di Jorong Kamboja Nagari Lubuk Jantan upah nya berdasarkan perekor dan satu kotaknya di isi 40 ekor puyuh.

Pekerja pembuat kandang puyuh tersebut mendatangi lahan untuk membuat kandang tersebut terjadi ijab dan qabul. Sebagaimana dialog antara Irsal dengan Wahyudi " yudi ambo kan mambuek kandang puyuah, ado karajo Yudi? (Yudi saya akan membuat kandang puyuh, ada kerja yudi?). kini ko lai indak ado karajo, sedang kosong. (lagi tidak ada kerja). Bara upah mambuek kandang puyuah tu yudi ?. (berapa upah membuat kandang puyuh yudi?). upah nyo paikuah, saikuahnyo tigo ribu, (upahnya per ekor, satu ekornya tiga ribu rupiah), yudi isi sakotaknyo 40 ikuah, jadi(iya).Hari senin mulai yudi karajo,(hari senin mulai yudi kerja), jadi(iya). (Irsal, Bustanil, Afrizall ,Jalinus, Reni Susanti pemilik kandang puyuh, Wahyudi, Ismail, Betrianto, Pendi pekerja pembuat kandang puyuhwawancara tanggal 10 Juli 2021)

Pada kutipan di atas dapat disimpulkan bahwa irsal meminta Wahyudi bekerja membuat kandang kandeang puyuh dengan upah perekor dengan isi 1 kotak 40 ekor dan siap kandangnya dalam jangka waktu satu Bulan. Di sana terdapat akad secara lisan yang dilakukan oleh Irsal dengan Wahyudi sehingga terbentuklah ijab dan qabul. Praktik akad yang dilakukan oleh pemilik kandang puyuh dan pembuat kandang puyuh tidak ada perjanjian yang menjelaskan tentang upah mengupah, sehingga akan merugikan salah satu pihak, hal ini bertentangan dengan syarat-syarat ljarah sebagai berikut:

1. Ujrah, disyaratkan diketahui jumlahnya oleh kedua belah pihak, baik dalam sewamenyewa maupun dalam pemberian upah-mengupah

2. Upah hendaknya jelas dengan bukti dan ciri yang bisa menghilangkan ketidakjelasan, maksudnya besar kecil upah dan bentuk upah seharusnya disebutkan.

3. Upah yang diberikan harus sesuai dan berharga. Maksud dari sesuai adalah sesuai dengan kesepakatan bersama, tidak dikurangi dan tidak ditambah. Upah harus sesuai dengan pekerjaan yang telah dikerjakan, tidaklah tepat jika pekerjaan yang diberikan banyak dan beraneka ragam jenisnya, sedangkan upah yang diberikan tidak seimbang. Berharga maksudnya upah tersebut dapat diberikan dengan uang.

4. Upah yang diberikan majikan bisa dipastikan kehalalannya, artinya barang-barang tersebut bukanlah barang curian, rampasan, penipuan, atau sejenisnya.

Jadi di antara 4 syarat-syarat ijarah di atas yang tidak terpenuhi yaitu Upah yang diberikan harus sesuai yaitu karena tidak sesuai dengan perjanjian dalam perjanjian dalam 1 kotak diisi 40 ekor puyuh dengan upah 40 ekor puyuh $\times \operatorname{Rp} 3.000,-=\operatorname{Rp} 120.000$ tetepi setelah kandang siap oleh pemilik kandang diisi 50 ekor puyuh dengan upahnya 50 ekor puyuh $x \operatorname{Rp} 3.000,-=\operatorname{Rp} 150.000$,- karena upahnya per ekor, upahnya tidak sesuai dengan perjanjian atau kesepakatan bersama, jelas karena tidak sesuai dengan kesepakatan bersama, sedangkan upah yang diberikan tidak sesuai karena kandang sudah siap diisi oleh pemilik kandang 50 ekor puyuh.(Yori Novendra, 2021, Hal 53)

Dalam perencanaan pekerjaan waktu pelaksanaaan pekerjaan harus direncanakan sebaik mungkin karena sangat mempengaruhi dalam hal memperkirakan biaya pekerjaan waktu pelaksanaan yang dibutuhkan untuk mengejarkan suatu pekerjaan ditentukan oleh jumlah tenaga kerja yang mengerjakannya. Dalam memperkerjakan waktu yang 
dibutuhkan untuk mengerjakan suatu suatu item pekerjaan, maka dari itu sebagai dasar dalam perencanaan tersebut digunakan analisa harga satuan untuk menghitung waktu yang dibutuhkan untuk mengerjakan pekerjaan tersebut.

Waktu untuk pembuatan kandang puyuh tergantung tergantung panjang kandang puyuh dan jumlah kotak tempat puyuh apabila kandang puyuhnya panjang maka memakan waktu yang lama dan kotak tempat puyuhnya banyak. Waktu penyelesaian pembuatan kandang puyuh di tetapkan 1satu bulan oleh pemilik kandang karena kandang tersebut ingin cepat di isi puyuh.(Wahyudi,Ismail,Betrianto,Pendi pekerja pembuat kandang puyuh wawancara tanggal 10 Juli 2021)

Waktu dalam pengerjaan pembuatan kandang puyuh di dalam perjanjian dalam satu bulan kandang puyuh siap. Maka seluruh pekerja pembuat kandang harus meningkatkan kecepatan untuk membuat kandang puyuh sehinggga pekerja tidak punya banyak waktu untuk istirahat. yang pekerja kandang puyuh inginkan adalah bagaimana kandang puyuh cepat selesai pada waktu yang telah ditetapkan. Berdasarkan prinsip keadilan penetapan harga dalam Islam ditetapkan kesepakatan antara pemilik kandang puyuh dan pekerja pembuat kandang puyuh dengan menjaga kepentingan keduanya. Islam pun mengatur bagaimana memberikan perhatian dengan menetapkan harga bagi pekerja sesuai dengan prinsip kelayakan dari upah. Upah tersebut menjadi tanggungjawab pemilik kandang puyuh untuk mempertimbangkan tingkat upah agar tidak terlalu rendah dan tidak terlalu tinggi.

Di dalam Islam kelayakan bermakna cukup dari segi pangan, sandang dan papan dan janganlah seseorang merugikan orang lain, dengan cara mengurangi hak-hak yang seharusnya diperolehnya. Dalam pengertian yang lebih jauh, hak-hak dalam upah bermakna bahwa janganlah mempekerjakan upah seseorang, jauh dibawah upah yang biasanya diberikan.

Penetapan harga pembuatan kandang puyuh adalah upahnya per ekor, dengan harga satu ekor Rp 3.000,-. Dan Pemilik kandang meminta satu kotak di isi dengan 40 ekor puyuh, maka jumlah upah 1 kotak 40 ekor x 3.000,- = Rp 120.000,-. Dan dalam 1 baris terdiri dari 75 kotak Sehingga satu barisnya dikenakan upah 120.000,- x 75 kotak $=\operatorname{Rp}$ 9.000.000,- . dan kandang puyuh tersebut terdiri 2 baris. Maka total upah kandang puyuh $\operatorname{Rp} 9.000 .000,-x \operatorname{Rp} 9.000 .000,-=\operatorname{Rp} 18.000 .000,-$. Penetapan harga pembuatan kandang sampai selesai yaitu Rp 18.000.000,-. (Irsal, Bustanil, Afrizall, Jalinus, Reni Susanti pemilik kandang puyuh, Wahyudi, Ismail, Betrianto, Pendi pekerja pembuat kandang puyuh wawancara tanggal 10 Juli 2021)

Sistem pembayaran pembuatan kandang puyuh di Jorong Kamboja Nagari Lubuk Jantan dilakukan sekali dalam seminggu pada setiap hari rabu yang mana pembayaran tersebut harus dilakukan pada hari itu karena pekerja pembuat kandang puyuh keluarganya membutuhkan gaji tersebut untuk membeli keperluan rumah tangga ke pasar. Dan gaji yang di bayarkan ke pekerja pembuat kandang hari kerja selama satu minggu. Pemilik kandang puyuh memberikan upah dengan waktu yang telah disepakati tanpa adanya penangguhan atau penundaan pembayaran upah, karena upah tersebut sangat dibutuhkan oleh pekerja pembuat kandang puyuh untuk memenuhi kebutuhannya, seperti untuk makan dan biaya kehidupan sehari-hari. Kalau upah 
tersebut tidak dibayarkan tentunya pekerja tidak mempunyai uang untuk memenuhi kebutuhan sehari-hari karena pekerjaan tersebut merupakan mata pencahariannya, Keadaan seperti ini sangat menyulitkan pekerja, maka sudah menjadi kewajiban bagi pemberi kerja untuk membayar upah tepat waktu agar tidak ada pihak yang merasa dirugikan. (Irsal, Bustanil, frizall, Jalinus, Reni Susanti pemilik kandang puyuh, Wahyudi, Ismail, Betrianto, Pendi pekerja pembuat kandang puyuhwawancara tanggal 10 Juli 2021)

Upaya yang dilakukan para pihak dalam hal terjadinya perselisihan antara pembuat kandang dengan pemilik kandang puyuh cara melihat kesepakatan awal dimana kesepakan tersebut pembuatan kandang puyuh dengan upah perekor puyuh, dengan harga satu ekor Rp 3.000,-.pemilik kandang meminta satu kotak di isi dengan 40 ekor puyuh, maka jumlah upah per kotak 40 ekor x 3.000,- = Rp 120.000,-. Sehingga satu barisnya dikenakan upah 120.000,- x 75 kotak $=\operatorname{Rp} 9.000 .000,-$.

Pandangan fiqh muamalah dalam ayat Al quran surat Al-Baqarah: 276 menjelaskan bahwa Dalam perjanjian (tentang upah) kedua belah pihak diperintahkan untuk bersikap jujur dan adil dalam semua urusan mereka, sehingga tidak terjadi tindakan aniaya terhadap orang lain dan tidak merugikn kpntingan diri sendiri. Penganiayaan terhadap pekerja ialah jika pemilik kandang tidak membayar secara adil dan bagian yang sah. Sedangkan yang imaksud dengan menganiaya dalam perjanjian pembuatan kandang puyuh dalam 1 kotak di isi 40 ekor puyuh tetapi setelah kandang siap oleh pemilik kandang puyuh di isi 50 ekor puyuh dan upah pembuatan kandang puyuh tersebut per ekor, karena upahnya per ekor tukang dirugikan. Oleh karena itu Al Qur'an memerintahkan kepada pemilik kandang untuk membayar tukang dengan bagian yang sesuai dengan perjanjian tetapi pemilik kandang melanggar perjanjian yang telah di sepakati, dan pada saat yang sama dia telah menyelamatkan kepentingan sendiri. Dan jika ia tidak mampu mengikuti anjuran Al Qur'an ini maka dia akan dihukum didunia ini oleh negara Islam dan dihari kemudian oleh Allah. . Dan Islam sangat melarang menzholimi orang lain

Proses penyelesaian perselisihan ini dilakukan dengan cara musyawarah dan negosisai antara pembuat kandang dan pemilik kandang, diantaranya: upah-mengupah pembuatan kandang puyuh merugikan pihak tukang meminta kerugiannya kepada pihak yang memmpunyai kandang untuk dapat menggantinya, tetapi pihak pemilik kandang cuman diam tidak menggantinya. (Irsal, Bustanil, Afrizall, Jalinus, Reni Susanti pemilik kandang puyuh, Wahyudi, Ismail, Betrianto, Pendi pekerja pembuat kandang puyuhwawancara tanggal 10 Juli 2021)

Dari penjelasan diatas dapat dilihat bahwa adanya bentuk kerugian yang terdapat pada pihak pekerja pembuat kandang dilihat dari upah mengupah pembuatan kandang puyuh. Jika di tinjau dari fiqh muamalah maka sistem upah mengupah yang seperti ini jelas dilarang karena termasuk Gharar, yang mana dalam hal ini upah mengupah tersebut tidak ada kesesuaian karena pemilik kandang dalam perjanjiannya 1 kotak di isi 40 ekor puyuh tetapi setelah kandang sudah siap pemilik kandang mengisi 1 kotak dengan 50 ekor puyuh, dan tukang rugi karena upahnya perekor. gharar dilarang dalam Islam, Praktik yang terjadi Di Jorong Kamboja Kecamatan Lintau Buo Utara Kabupaten Tanah Datar, yang mana di awal perjanjian di isi 40 ekor puyuh dengan 1 barisnya 75 kotak, akan tetapi upah berdasarkan perekor, Di dalam hal ini terdapat unsur ketidakjelasan dalam 
upah mengupah pembuatan kandang puyuh. Adanya unsur ketidakjelasan dalam fiqih muamalah tidak dibolehkan. Upah mengupah membuat kandang puyuh tersebut ada nya unsur Gharar di karenakan.

1. Akad ljarah yang terlanggar

Selama ini pekerja pembuat kandang puyuh sudah melakukan pekerjaan nya dengan baik, maka hak nya juga harus dipenuhi. Syekh Qardhawi menyatakan bahwa bekerja yang baik merupakan kewajiban karyawan atas hak upah yang diperolehnya, demikian juga memberi upah merupakan kewajiban perusahaan atas hak hasil kerja karyawan yang diperolehnya.

Menurut ulama Fiqh setiap akad mempunyai akibat hukum, yaitu tercapainya sasaran yang ingin dicapai sejak semula sampai pemindahan hak milik dari kedua belah pihak yang berakad, dan akad itu bersifat mengikat bagi kedua belah pihak yang melakukan akad, bagi pihak-pihak yang berakad tidak boleh dibatalkan kecuali yang disebabkan oleh hal-hal syara' seperti terdapat cacat pada objek, akad ini tidak memenuhi salah satu rukun atau syara'.(Hayatul Nupus, 2020, Hal 52)

2. Para pihak yang melanggar

Allah memusuhi orang-orang yang melakukan hal-hal yang dilarang agama, seperti dalam hadist yang diriwayatkan HR.Ibnu Majah, sebagai berikut:

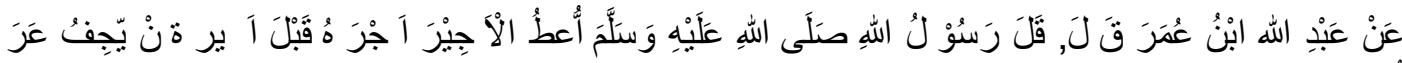

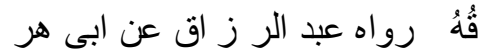

Artinya: “ Dari Abdullah bin 'Umar ia berkata: telah bersabda Rasulullah “ berikanlah upah pekerja sebelum keringatnya kering”. ( HR.Ibnu Majah)

Maksud hadits ini adalah bersegera menunaikan hak si pekerja setelah selesainya pekerjaan, begitu juga bisa dimaksud jika telah ada kesepakatan pemberian upah.

3. Faktor yang menyebabkan upah mengupah tersubut ada unsur Gharar

Dalam perjanjian (tentang upah) kedua belah pihak diperintahkan untuk bersikap jujur dan adil dalam semua urusan mereka, sehingga tidak terjadi tindakan aniaya terhadap orang lain dan tidak merugikn kepntingan diri sendiri. Penganiayaan terhadap pekerja ialah jika pemilik kandang puyuh tidak membayar secara adil dan bagian yang sah sedangkan yang imaksud dengan menganiaya dalam perjanjian pembuatan kandang puyuh dalam 1 kotak di isi 40 ekor puyuh tetapi setelah kandang siap oleh pemilik kandang puyuh di isi 50 ekor puyuh dan upah pembuatan kandang puyuh tersebut per ekor, karena upahnya per ekor tukang dirugikan. Oleh karena itu Al Qur'an memerintahkan kepada pemilik kandang untuk membayar tukang dengan bagian yang sesuai dengan perjanjian tetapi pemilik kandang melanggar perjanjian yang telah di sepakati, dan pada saat yang sama dia telah menyelamatkan kepentingan sendiri. Dan jika ia tidak mampu mengikuti anjuran Al Qur'an ini maka dia akan dihukum didunia ini oleh negara Islam dan dihari kemudian oleh Allah.

Walaupun terjadi akad yang berfungsi bukti kerelaan, namun dalam hati pekerja pembuat kandang puyuh tidak rela. Masyarakat banyak yang tidak paham atau 
tidak tahu, tentang ajaran Islam melarang apapun yang merugikan salah satu pihak yang bermuamalah, dan setiap kerugian atau kemudaran itu harus di hilangkan.

Maksudnya disini ada yang dirugikan yang dirasakan oleh satu pihak yang mengakibatkan pihak tersebut menjadi rugi. Oleh karena itu segala sesuatu yang membawa kepada kemudaratan kepada orang lain harus dihilangkan. Seperti yang terdapat di Jorong Kamboja Nagari Lubuk Jantan dalam menetapkan upah harus sesuai dengan perjanjian tidak ada pihak yang merasa tidak dirugikan dan terhindar dari gharar (ketidakjelasan).

Sesuai dengan transaksi upah mengupah yang menguntungkan salah satu pihak yang terjadi di Jorong Kamboja Nagari Lubuk Jantan Kabupaten Tanah Datar, yang terjadi sebagai berikut:

a. Kecurangan di bidang upah mengupah seperti yang terjadi dalam upah mengupah pembuatan kandang puyuh yang mana upah dalam pembuatan kandang puyuh dihitung dari per ekor puyuh dalam kotak, dengan harga satu ekor Rp 3.000,-. Apabila pemilik kandang meminta satu kotak di isi dengan 40 ekor puyuh, maka jumlah upah per kotak 40 ekor $\times 3.000,-=\operatorname{Rp} 120.000,-$. Sehingga satu barisnya dikenakan upah 120.000,- x 75 kotak $=\operatorname{Rp} 9.000 .000,-$ dengan jumlah 1 baris kandang puyuh ber isi 3.000 ekor puyuh dan ternyata setelah kandang siap pemilik mengisi satu kotak dengan 50 ekor puyuh. Jika di isi satu kotaknya 50 ekor puyuh oleh pemilik kandang, maka tukang mengalami kerugian dalam satu kotaknya Rp 3.000.- x 10 ekor puyuh $=$ Rp 30.000,- Satu baris nya 75 kotak kalau di isi 50 ekor 1 kotak nya dalam 1 baris nya puyuh berjumlah 75 kotak x 50 ekor $=3.750$ ekor puyuh maka tukang mengalami kerugian 1 kotak nya sebanyak $\operatorname{Rp} 30.000,-x 75$ kotak $=\operatorname{Rp} 2.250 .000,-$ dalam 1 barisnya dan tukang mengakibatkan rugi. terjadi di Jorong Kamboja Nagari Lubuk Jantan Kabupaten Tanah Datar.

b. Dalam pandangan fiqh muamalah dalam ayat Al quran surat Al-Baqarah: 276 menjelaskan bahwa Dalam perjanjian (tentang upah) kedua belah pihak diperintahkan untuk bersikap jujur dan adil dalam semua urusan mereka, sehingga tidak terjadi tindakan aniaya terhadap orang lain dan tidak merugikn kpntingan diri sendiri. Penganiayaan terhadap pekerja ialah jika pemilik kandang tidak membayar secara adil dan bagian yang sah. Sedangkan yang imaksud dengan menganiaya dalam perjanjian pembuatan kandang puyuh dalam 1 kotak di isi 40 ekor puyuh tetapi setelah kandang siap oleh pemilik kandang puyuh di isi 50 ekor puyuh dan upah pembuatan kandang puyuh tersebut per ekor, karena upahnya per ekor tukang dirugikan. Oleh karena itu Al Qur'an memerintahkan kepada pemilik kandang untuk membayar tukang dengan bagian yang sesuai dengan perjanjian tetapi pemilik kandang melanggar perjanjian yang telah di sepakati, dan pada saat yang sama dia telah menyelamatkan kepentingan sendiri. Dan jika ia tidak mampu mengikuti anjuran Al Qur'an ini maka dia akan dihukum didunia ini oleh negara Islam dan dihari kemudian oleh Allah. . Dan Islam sangat melarang menzholimi orang lain 


\section{KESIMPULAN}

Berdasarkan hasil penelitian dan pembahasan pada bab-bab terdahulu dapat disimpulkan bahwa tata cara upah mengngupah pembuatan kandang puyuh yang terjadi di Jorong Kamboja Nagari LubukJantan Kabupaten Tanah Datar sebagai berikut:

1. Pelaksanaan sistem upah mengupah dalam pembuatan kandang puyuh di Jorong Kamboja Nagari Lubuk Jantan Kabupaten Tanah Datar, pemilik kandang meminta di isi satu kotak 40 ekor puyuh, maka jumlah upah satu kotak Rp 120.000,--. Apabila satu deret upahnya Rp 9.000.000,- kemudian setelah kandang siap pemilik mengisi satu kotak dengan 50 ekor puyuh. Di isi satu kotaknya 50 ekor puyuh oleh pemilik kandang, maka tukang mengalami kerugian dalam satu kotaknya Rp 30.000,- jika satu deretnya 75 kotak maka tukang mengalami kerugian sebanyak Rp 2.250.000,- dalam satu deret kandang puyuh.

2. Tinjauan fiqh muamalah terhadap pelaksanaan upah mengupah pembuatan kandang puyuh di Jorong Kamboja Nagari Lubuk Jantan tidak sesuai dengan hukum Islam (menyalahi aturan dalam Fiqh Muamalah). Di Jorong Kamboja Nagari Lubuk Jantan tidak sesuai dengan perjanjian karena ada unsur Gharar tidak dibolehkan karena akan menimbulkan kerugian disalah satu pihak atau kesepakatan bersama dan merugikan pihak yang bersangkutan.

\section{DAFTAR PUSTAKA}

Aksin, N. (2018). Upah dan Tenaga Kerja. Jurnal Hukum Ketenagakerjaan Dalam Islam. Semarang: Jurnal Penelitian Vol 1 No. 2.

Al Aji, R.H. (2019). Penangguhan Dalam Upah Mengupah Panen Sawit Menurut Hukum Islam, Jambi: Skripsi Penelitian

Hari, S \& M. Noor. 2019. Pengantar Ilmu Fiqih. Edisi Ketujuh. Cetakan Ketujuh. Pena Salsabila. Surabaya.

Novendra, Y. (2021). Pelaksanaan Upah Mengupah Pengambilan Cabe Di Tiga Batur Sungai Tarab Menurut Perspektif Figh Muamalah. Batusangkar: Skripsi Penelitian

Nupus, H. (2020). Pelaksanaan Upah Mengupah Dalam Membersihkan Bawang Menurut Perpektif Figh Mu'amalah.Batusangkar: Skripsi Penelitian

Pertiwi, D. A., (2020). Tinjauan Hukum Islam Tentang Upah Sebagai Pemain Kuda Lumping. Lampung: Skripsi Penelitian

Purnama, H. J. (2019). Tinjauan Fikih Muamalah Terhadap Praktik Sewa Menyewa Kios Di Pasar Desa Milangsri Kecamatan Panekan Kabupaten Megatan. Ponorogo: Skripsi Penelitian

Ridwan, (2017). Regulasi Upah Buruh Dalam Figh. Purwokerto: Jurnal, Hal 270

Sari, D N., (2020). Tinjauan Hukum Islam Tentang Upah Mengupah Duplikat Kunci Tanpa Hak Kyiar. Lampung: Skripsi Penelitian

Irma, S. (2017). Praktik Upah Mengupah Batanam Dan Basiang Di Jorong Carano Batirai Nagari Rao-Rao Kecamatan Sungai Tarab Dalam Perpektif Fikih Muamalah. Batusangkar: Skripsi Penelitian 


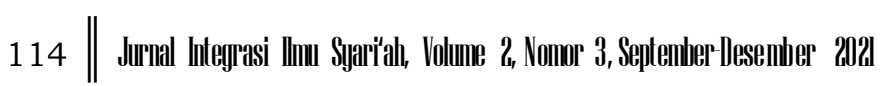

Sugiyono, (2007). Metode Penelitian Kuantitatif Kualitatif dan RED. Bandung: Alfabeta.

Sumartini, (2019). Tinjauan Hukum Islam Tentang Praktik Upah Mengupah Dalam Pengairan Sawah Dengan Sistem Lajur. Lampung: Skripsi Penelitian

Syamsuryani, F. 2019 Pelaksanaan Upah bagi Buruh Tani dalam Perspektif Figh Muamalah (Studi Kasus Nagari Sibarambang Kecamatan X Koto Diatas Kabupaten Solok). Batusangkar: Skripsi Penelitian

Armansyah, W. (2017). Upah Berkeadilan Ditinjau dari Perspektif Islam. Palembang: Jurnal penelitian, Vol 5

Yumerlin, D. (2018). Service Handphone Di Koto Baru Kabupaten Dharmasraya (Tinjauan Hukum Islam Terhadap Akad, Ujrah dan Tanggung Jawab). Batusangkar: Skripsi Penelitian. 